JRPB, Vol. 7, No. 1, Maret 2019, Hal. 43 - 51

DOI: $10.29303 /$ jrpb.v7i1.100

ISSN 2301-8119, e-ISSN 2443-1354

Tersedia online di http://jrpb.unram.ac.id/

\title{
PENGARUH INTENSITAS CAHAYA LAMPU DAN LAMA PENYINARAN TERHADAP PERTUMBUHAN TANAMAN KANGKUNG (Ipomea reptans Poir) PADA SISTEM HIDROPONIK INDOOR
}

The Influence of Light Intensity and Duration on Kangkung (Ipomea reptans Poir) Plant Growth in Indoor Hydroponics System

\section{Safinatul Aulia ${ }^{1}$, Ansar ${ }^{1, *)}$, Guyup Mahardhian Dwi Putra ${ }^{1}$}

${ }^{1}$ Program Studi Teknik Pertanian, Fakultas Teknologi Pangan dan Agroindustri, Universitas Mataram

Email*): ansar72@unram.ac.id

Diterima: Januari 2019

Disetujui: Maret 2019

\begin{abstract}
Fluorescent lamp is one type of lamp that often used as a light source in an indoor hydroponic system. The color of the lamp that matches the plant needs to be determined precisely in order to obtain optimal plant growth. The purpose of this study was to determine the effect of light intensity and light color on growth of kangkung (Ipomea reptans Poir) in indoor hydroponic system. The study used 2 color variances of white and yellow lights. White light irradiation treatment used lamps with power of 52 watts (P1), 42 watts (P2), 32 watts (P3), 24 watts (P4) and 20 watts (P5). Whereas yellow lights used lamps with power of 24 watts $(K 1), 20$ watts (K2), 12 watts (K3), 8 watts (K4) and 5 watts (K5). Each treatment consists of 4 plants with a total of 40 plant samples. Crop production data were analyzed using two-factor variance analysis and presented in tables and graphs. Plant irradiation was carried out for 10 hours with white lights and 24-hour with yellow lights. The research parameters observed were light intensity, lamp color, duration of irradiation, and air temperature. The results showed that the highest artificial light intensity was obtained by irradiating white lights with 42 watts of radiation duration of 10 hours, while for the growth of water spinach plants with irradiation 24 hours using yellow lights did not experience much growth. The white light treatment gives better results with indicators of plant height, number of leaves, total weight, root weight and length of plant roots when compared with other treatments
\end{abstract}

Keywords: indoor hydroponics, light intensity, duration of irradiation, water spinach plant

\begin{abstract}
ABSTRAK
Lampu neon merupakan salah satu jenis lampu yang sering digunakan sebagai sumber cahaya dalam sistem hidroponik di dalam ruang (indoor). Warna lampu yang sesuai dengan tanaman perlu ditentukan secara tepat agar diperoleh pertumbuhan tanaman yang optimal. Tujuan dari penelitian ini adalah untuk mengetahui pengaruh intensitas cahaya lampu dan warna lampu terhadap pertumbuhan tanaman kangkung (Ipomea reptans Poir) pada sistem hidroponik
\end{abstract}


indoor. Penelitian menggunakan 2 variansi warna yaitu lampu putih dan kuning. Perlakuan penyinaran menggunakan lampu putih dengan daya 52 watt (P1), 42 watt (P2), 32 watt (P3), 24 watt (P4) dan 20 watt (P5) sedangkan lampu kuning dengan daya sebesar 24 watt (K1), 20 watt (K2), 12 watt (K3), 8 watt (K4) dan 5 watt (K5). Setiap perlakuan terdiri dari 4 tanaman dengan total 40 sampel tanaman. Data produksi tanaman dianalisis menggunakan analisis varian dua faktor dan disajikan dalam bentuk tabel dan grafik. Penyinaran tanaman dilakukan selama 10 jam dengan lampu putih dan penyinaran 24 jam dengan lampu kuning. Parameter penelitian yang diamati yaitu intensitas cahaya, warna lampu, lama penyinaran dan suhu udara. Hasil penelitian menunjukkan bahwa intensitas cahaya penyinaran buatan tertinggi diperoleh pada penyinaran lampu warna putih dengan 42 watt lama penyinaran 10 jam, sedangkan untuk pertumbuhan tanaman kangkung dengan penyinaran 24 jam menggunakan lampu warna kuning tidak banyak mengalami pertumbuhan. Perlakuan lampu putih memberikan hasil lebih baik dengan indikator tinggi tanaman, jumlah daun, berat total, berat akar dan panjang akar tanaman jika dibandingkan dengan perlakuan lainnya.

Kata kunci: hidroponik indoor, intensitas cahaya, lama penyinaran, tanaman kangkung

\section{PENDAHULUAN}

Indonesia merupakan negara agraris, sektor pertanian indonesia salah satu sektor penting sebagai penopang perekonomian nasional. Penduduk Indonesia dominan bermata pencaharian di bidang pertanian. Hasil yang diharapkan dari sektor pertanian belum memenuhi kebutuhan masyarakat. Kondisi lahan pertanian di Indonesia saat ini kian hari semakin berkurang, sementara pemenuhan kebutuhan pangan dari hasil pertanian semakin meningkat. Untuk mengatasi kendala sektor pertanian tersebut dapat menerapkan salah satu kegiatan teknologi budidaya yaitu sistem hidroponik.

Teknologi budidaya secara sistem hidroponik memiliki tingkat kesukaran dalam proses pengelolahannya. Oleh karena itu, banyak hal yang harus diperhatikan di sistem hidroponik yaitu $\mathrm{pH}$ larutan nutrisi, debit aliran air, kemiringan talang, media tanam dan lain-lain. Dengan menggunakan sistem hidroponik tersebut, ada beberapa kendala yang muncul.

Salah satu kendalanya yaitu adanya lingkungan yang kurang mendukung, seperti di saat musim hujan. Kondisi tanaman tidak mengalami proses fotosintesis secara sempurna karena kurangnya penyinaran cahaya matahari. Dengan menggunakan sistem hidroponik indoor, dapat mengatasi kendala kurangnya cahaya matahari dan menjadi alternatif yang potensial karena suhu ruangan tidak sepanas di luar, sehingga tanaman bisa tumbuh sehat secara maksimal.

Penggunaan bola lampu pada sistem hidroponik indoor ini dapat membantu mengoptimalkan proses fotosintensis. Penggunaan bola lampu untuk tanaman dapat diatur sesuai kebutuhan cahaya tanaman itu, salah satu jenis lampu yang dapat di gunakan yaitu lampu neon atau fluorescent lamp, dimana lampu neon memiliki pencahayaan yang lebih tinggi dibandingkan jenis lampu lainnya sehingga tanaman yang dihasilkan lebih baik.

Selain pemilihan jenis lampu, pemilihan daya yang tepat untuk perkembangan tanaman sangat penting. Daya lampu yang besar akan menghasilkan panas atau cahaya yang tinggi dan dapat mempengaruhi pertumbuhan tanaman. Kurangnya pencahayaan pada tanaman akan menghasilkan klorofil sedikit dan fotosintesis rendah. Sedangkan untuk tanaman yang cocok di terapkan secara hidroponik indoor yaitu tanaman sayuran seperti tanaman kangkung (Ipomea reptans Poir).

Tanaman kangkung dapat dibudidayakan di dalam ruang dengan bantuan penyinaran buatan yaitu dengan menggunakan lampu, daya lampu yang akan digunakan tanaman perlu diteliti terlebih dahulu. Lampu neon, salah satu lampu yang 
paling efektif untuk pertumbuhan tanaman pada sistem hidroponik indoor, tetapi belum diketahui daya yang dibutuhkan tanaman kangkung tersebut sehingga perlu dilakukan penelitian untuk mengkaji pengaruh daya lampu neon terhadap pertumbuhan tanaman kangkung yang dibudidayakan dengan sistem hidroponik di dalam ruangan (indoor).

Berdasarkan uraian diatas, perlu dilakukan penelitian yang berjudul: Pengaruh Intensitas Cahaya Lampu Dan Lama Penyinaran Terhadap Pertumbuhan Tanaman Kangkung (Ipomea reptans Poir) Pada Sistem Hidroponik Indoor sehingga mampu menggantikan sinar matahari selama proses fotosintesis berlangsung.
AB Mix, benih tanaman sayuran (kangkung), air, cocopeat, kain flannel dan botol pastik.

\section{Parameter penelitian}

Parameter yang di amati, yaitu:

1. Intensitas cahaya (lux)

2. Lama penyinaran (jam)

3. Suhu $\left({ }^{\circ} \mathrm{C}\right)$

4. Pertumbuhan tanaman kangkung

\section{Prosedur penelitian}

Langkah awal yang dilakukan adalah melakukan pesemaian bibit kangkung selama 2 minggu. Setelah itu merancang konstruksi hidroponik indoor dengan ukuran 200 x 70 x $200 \mathrm{~cm}$ dari kerangka kayu dan sekat menggunakan papan triplek. Desain penelitian seperti disajikan pada gambar 1 .

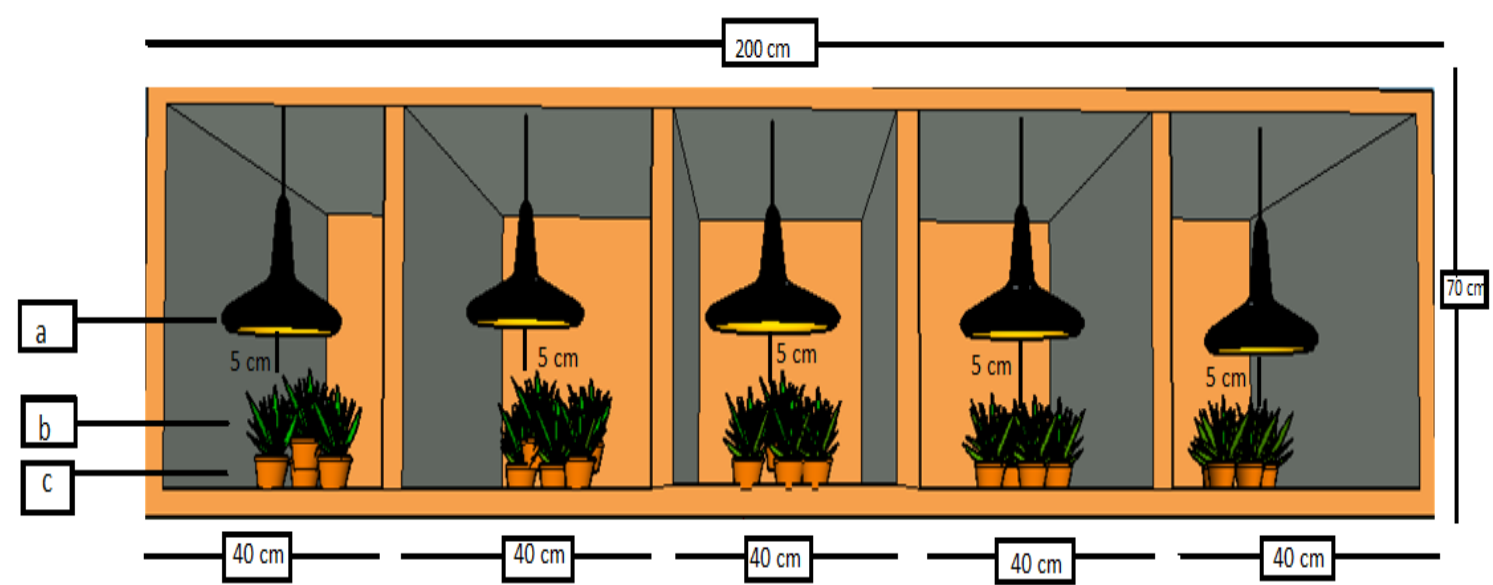

Gambar 1. Rancangan Desain Penelitian

Keterangan: (a) lampu neon, (b) tanaman kangkung, (c) media tanam

\section{METODE PENELITIAN}

\section{Bahan dan Alat}

Alat-alat yang digunakan dalam penelitian ini, yaitu wadah penyemaian, ruang tanam 10 box, 5 lampu neon berwarna putih dengan besaran watt 52, 42, 32, 24 dan 20 dan 5. Lampu neon berkuning dengan masing-masing besaran watt 24, 20, 12,8 dan 5. penggaris, timbangan, lux meter, exhaust fan 10 buah, power analyzer, hygrometer dan perlengkapan kerja seperti alat tulis, kalkulator, dan komputer

Bahan-bahan yang digunakan dalam penelitian ini, yaitu larutan nutrisi (hasil melarutkan pupuk dengan air) yaitu pupuk
Lampu neon dipasang pada bagian atas kotak ruang penanaman untuk masingmasing ruang, sehingga jumlah lampu yang digunakan sebanyak 10 lampu. Memasukkan nutrisi pada sumbu (wick) sebelum tanaman dipindahkan. Nutrisi yang digunakan pada semua perlakuan adalah nutrisi AB Mix.

Selanjutnya bibit kangkung yang telah disemai dipindahkan ke media tanam hidroponik sistem wick. Diletakkan hidroponik sumbu (wick) yang telah ditanami bibit kangkung ke dalam greenhouse selama satu minggu sebagai proses adaptasi. Tanaman hidroponik yang telah diadaptasi dipindahkan ke dalam ruang penanaman 
yang telah dipasang lampu neon dan exhaust fan.

Dilakukan pengukuran $\mathrm{pH}$ dan EC (Electrical Conductivity) menggunakan alat $\mathrm{pH}$ meter dan EC meter dan intensitas cahaya dan warna lampu setiap hari pada pukul 07.00-08.00 WITA, 12.00-13.00 WITA dan 16.00-17.00 WITA dengan menggunakan alat lux meter. Dilakukan pengukuran daya lampu setiap hari pada pukul 07.00-08.00 WITA, 12.00-13.00 WITA dan 16.00-17.00 dengan menggunakan alat power analyzer.

Pengambilan data suhu di dalam ruangan dilakukan setiap hari pada pukul 07.00-08.00 WITA, 12.00-13.00 WITA dan 16.00-17.00 menggunakan alat hygrometer. Mengamati pertumbuhan tanaman dengan durasi penyinaran selama 10 jam dengan lampu neon putih dan lama penyinaran selama 24 jam dengan menggunakan lampu neon kuning setiap sekali seminggu selama 20 hari. Setelah itu dilakukan pengukuran tinggi batang $(\mathrm{cm})$, jumlah daun (helai), panjang akar $(\mathrm{cm})$, berat akar (gram) dan berat tanaman (gram) pada saat panen.

\section{HASIL DAN PEMBAHASAN}

\section{Intensitas Cahaya}

Pengukuran intensitas cahaya di dalam ruang tanaman di lakukan tiga kali sehari yaitu pada pagi hari, siang hari dan sore hari. Pengukuran intensitas cahaya juga dilakukan tiga kali ulangan yang bertujuan untuk mengetahui pengaruh intensitas cahaya terhadap pertumbuhan kangkung (Ipomea reptans Poir). Pengukuran intensitas cahaya yang dihasilkan oleh beberapa perlakuan dari perbedaan warna lampu yaitu lampu berwarna putih $(\mathrm{P})$ dan lampu berwarna kuning $(\mathrm{K})$ dengan jenis lampu yang sama yaitu lampu neon. Selama penelitian berlangsung dapat di peroleh, rata-rata intensitas cahaya pada lampu putih $(\mathrm{P})$ dan lampu kuning (K) pagi hari, siang hari dan pada sore hari pada gambar 2 .

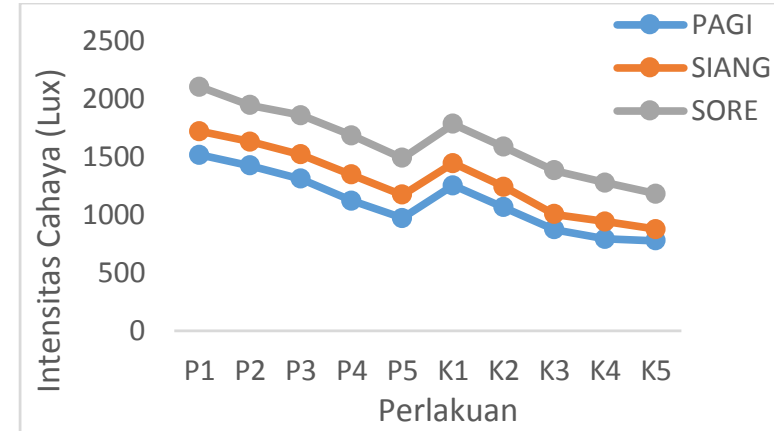

Gambar 2. Grafik Hasil Pengukuran Intensitas Cahaya pada Pagi, Siang dan Sore Hari

Gambar 2 menunjukkan nilai intensitas cahaya di dalam ruang tanam. Intensitas cahaya Sebagai pengganti sinar matahari, proses fotosintesis di dalam ruang tanaman digantikan dengan cahaya lampu neon dengan dua warna yaitu warna putih dan warna kuning. Pengukuran nilai intensitas cahaya yang dilakukan pada pagi, siang dan sore hari menunjukkan bahwa rata-rata intensitas cahaya tertinggi di dalam ruang tanam menggunakan lampu berwarna putih (P) yaitu 1520,53 lux dan rata-rata intensitas cahaya yang rendah pada lampu berwarna kuning (K) yaitu 1165,2 lux. Warna putih cenderung memiliki lumen yang lebih tinggi daripada kuning. Menurut Widiastuti (2004) tanaman sayur seperti kangkung membutuhkan cahaya minimal 20.000 lux.

Berdasarkan hasil analisis varians menunjukkan bahwa nilai F-hitung $(880,587)$ lebih besar dari pada F-tabel $(3,5545)$. Hal ini di menunjukkan bahwa intensitas cahaya berpengaruh signifikan terhadap perlakuan warna lampu, intensitas cahaya di dalam ruang tanam tidak stabil setiap harinya. Hal ini disebabkan karena rangkaian listrik yang menghubungkan lampu pada masing-masing rumah tanam memiliki hambatan yang berbeda pada rangkaian parallel. Sesuai dengan hukum Ohm, besar kecilnya nilai hambatan yang dihasilkan suatu penghantar listrik dipengaruhi oleh panjang penghantar hambatan dan jenis dari bahan penghantar listrik itu sendiri. Semakin panjang jarak suatu penghantar listrik yang terpasang akan semakin besar nilai hambatan penghantar tersebut, semakin besar nilai hambatan jenis 
dari bahan penghantar, maka semakin besar nilai hambatan penghantar tersebut, semakin besar nilai tahanan atau hambatan jenis dari bahan penghantar, maka semakin besar nilai hambatan penghantar tersebut (Jalaludin, 2007).

Pada ruang tanam lampu putih $(\mathrm{P} 1, \mathrm{P} 2$, P3, P4 dan P5) mengalami pertumbuhan tanaman sangat cepat sedangkan lampu neon yang berwarna kuning (K1, K2, K3, K4 dan K5) hanya mengalami sedikit pertumbuhan dan memiliki nilai rata-rata intensitas yang sedikit dibandingkan intensitas cahaya lampu berwarna putih.

Berdasarkan hasil tersebut dapat diketahui bahwa tanaman yang menggunakan lampu berwarna putih memiliki pertumbuhan lebih cepat dibandingkan dengan menggunakan lampu berwarna kuning, tanaman membutuhkan cahaya berwarna kuning hanya dalam persentase yang sangat kecil meskipun durasi lampu warna kuning disinari selama 24 jam.

\section{Warna Lampu}

Tabel 1 menunjukkan bahwa lampu yang berwarna putih lebih baik dibandingkan lampu berwarna kuning, hal ini dapat dilihat pada pertumbuhan tanaman yang lebih baik dari jumlah helai, tinggi tanaman, berat total, berat akar, dan panjang akar. Pengukuran intensitas cahaya di dalam ruang tanam menunjukkan bahwa nilai F-hitung lebih besar $(880,587)$ dari pada nilai F-tabel $(3,5545)$. Hal ini menunjukkan bahwa warna lampu berpengaruh secara signifikan terhadap pertumbuhan tanaman. berbeda-beda. Warna lampu sangat berpengaruh pada pertumbuhan tanaman, penggunaan lampu yang berwarna putih sangat mempercepat pertumbuhan kangkung, karena pada dasarnya tanaman sangat membutuhkan cahaya yang lebih terang untuk menggantikan sinar matahari sebagai proses fotosintesis (Acero, 2013).

\section{Tinggi Tanaman}

Pengukuran tinggi tanaman dilakukan setiap satu minggu sekali dengan mengukur tinggi dari batas pangkal batang sampai dengan pangkal daun tertinggi pada masingmasing tanaman. Hasil pengamatan tinggi tanaman pada setiap perlakuan dapat dilihat pada gambar 3 .

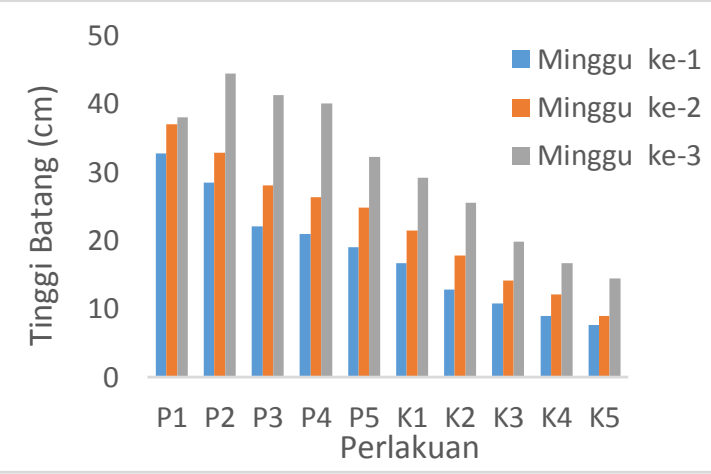

Gambar 3. Grafik Rata-rata Tinggi Batang Tanaman Kangkung pada Ruang Tanam

Berdasakan gambar 3 dapat dilihat bahwa rata-rata tinggi batang tanaman terbaik diperoleh pada perlakuan lampu putih dengan 42 watt (P2). Pengukuran nilai tinggi batang tanaman menggunakan analisis varian menujukkan hasil yang signifikan dengan

Tabel 1. Perbandingan Hasil Produksi Tanaman Kangkung Berdasarkan Perbedaan Warna.

\begin{tabular}{ccccccc}
\hline WL & IC $($ LUX) & JD (helai) & Tt $(\mathrm{cm})$ & BT $(\mathrm{gr})$ & BA (gr) & PA (cm) \\
\hline Putih & 1944 & 20 & 44,4 & 37 & 22 & 29 \\
Kuning & 1784 & 9 & 29,2 & 22 & 20 & 19 \\
\hline
\end{tabular}

Ket: WL: warna lampu, IC: intensitas cahaya (lux), JD: jumlah daun (helai), Tt: tinggi tanaman (cm), BT: berat total (gr), BA: berat akar (gr), PA: panjang akar (cm)

Dengan mengetahui intensitas cahaya, yang dihasilkan lampu berwarna putih dan berwarna kuning, diketahui bahwa setiap warna lampu memiliki intensitas yang nilai F-hitung $(53,449)$ lebih besar dari pada F-tabel $(3,55)$. Tinggi tanaman pada lampu putih terbesar terletak pada lampu putih 42 watt dengan tinggi minggu pertama sebesar 
$28,5 \mathrm{~cm}$, minggu kedua sebesar $35,7 \mathrm{~cm}$ dan $44,4 \mathrm{~cm}$ pada minggu ketiga. Sedangkan tanaman yang mempunyai tinggi batang terendah berada pada P5 dengan daya 20 watt sebesar $19 \mathrm{~cm}$ minggu pertama, $24,8 \mathrm{~cm}$ minggu kedua dan $32,2 \mathrm{~cm}$ pada minggu ketiga. Pada ruang P1 (52 watt) tinggi tanaman pada minggu ketiga tidak mengalami banyak peningkatan, hal ini dikarenakan tanaman kangkung mengalami perlakuan gejala fotodestruktif karena pemberian cahaya secara terus menerus diatas 1750 lux.

Fotodesktruktif adalah tingginya intensitas cahaya yang mengakibatkan fotosintesis semakin tidak bertambah lagi dikarenakan tanaman mengalami batas titik jenuh cahaya sehingga bukan menjadi sumber energi tetapi sebagai perusak. Intensitas cahaya yang tinggi mengakibatkan temperatur daun meningkat, sebagai akibat menutupnya stomata, sehingga sebagaian klorofil menjadi pecah dan rusak (fotodestruktif). Menurut penelitian Suyanto, dkk., (2011) batas optimum tanaman menerima cahaya adalah 1750 lux.

Tinggi tanaman yang terbesar yang menggunakan lampu kuning dengan durasi penyinaran selama 24 jam terdapat di perlakuan K1 (24 watt) sebesar $16,7 \mathrm{~cm}$ pada minggu pertama, 21,5 minggu kedua dan 29,2 pada minggu ketiga. Dan tinggi tanaman yang terendah terletak pada tanaman yang disinari lampu dengan daya 5 watt (K5) sebesar $7,7 \mathrm{~cm}$ minggu pertama, $9 \mathrm{~cm}$ minggu kedua dan 14,5 pada minggu ketiga. Penggunaan lampu kuning tidak berpengaruh besar pada pertumbuhan tanaman karena tanaman hanya menerima sedikit cahaya yang berwarna kuning (Acero, 2013).

Warna lampu kuning diperlukan untuk fotosintesis dalam jumlah sedikit sehingga tidak berpengaruh terhadap pembentukan tanaman. Hasil pengamatan (Dhini, 2015), menunjukkan bahwa warna putih lampu neon dapat memberikan hasil yang lebih tinggi pada pertumbuhan tanaman dibandingkan lampu neon yang berwarna hijau, kuning, biru dan merah.
Tanaman kangkung yang dibudidayakan secara hidroponik akan berbeda dengan tanaman kangkung yang ditanam secara konvensional atau dengan tanah. Umumnya tinggi kangkung yang tumbuh secara konvensional yaitu 30-67 cm (Phina, 2014).

\section{Jumlah Daun Tanaman Kangkung}

Pengamatan jumlah daun dilakukan pada daun yang telah membuka sempurna setiap satu minggu sekali. Hasil pengamatan jumlah daun pada ruang tanam menggunakan lampu neon berwarna putih $(\mathrm{P})$ dan lampu berwarna kuning (K) serta di dalam greenhouse dapat dilihat pada gambar 4 .

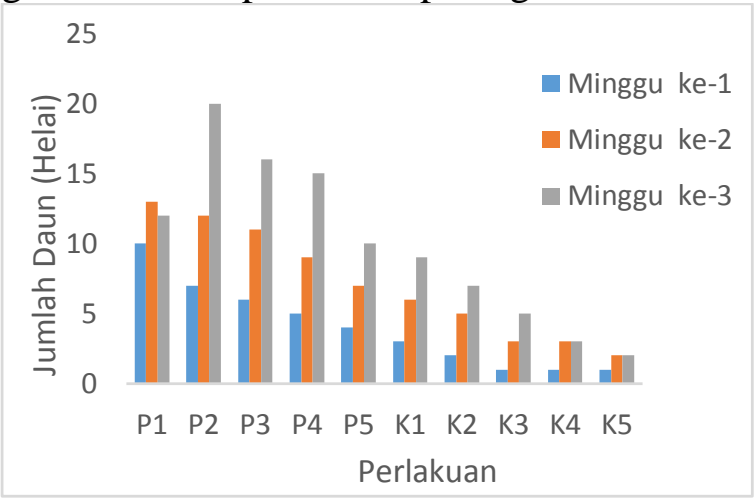

Gambar 4. Grafik Rata-Rata Jumlah Daun pada Pertumbuhan Kangkung

Berdasarkan gambar 4 menunjukkan bahwa jumlah daun terbanyak pada minggu ke-3 pada lampu berwarna putih. Pengukuran jumlah daun tanaman menggunakan analisis varian menujukkan hasil yang signifikan dengan nilai F-hitung $(20,325)$ lebih besar dari pada nilai F-tabel $(3,55)$. Lampu putih 42 watt (P2) memmpunyai jumlah daun sebanyak 20 helai, kemudian jumlah daun terendah pada perlakuan lampu kuning 5 watt (P5) sebanyak 9 helai, sedangkan pada perlakuan menggunakan lampu berwarna kuning jumlah daun tertinggi terletak pada 24 watt (K1) sebanyak 9 helai, dan jumlah daun terendah pada perlakuan 5 watt (K5) sebanyak 2 helai.

Perlakuan dengan penyinaran menggunakan lampu putih, daun tanaman terlihat berwarna hijau dan segar, sedangkan pada perlakuan penyinaran menggunakan lampu kuning daun terlihat tidak 
berkembang, hal ini disebabkan karena lampu kuning menghasilkan suhu panas yang tinggi sehingga daun tidak mengalami pertumbuhan bahkan daun mengalami layu dan mati.

Daun merupakan komponen utama suatu tumbuhan dalam berfotosintesis. Proses fotosintesis akan optimal apabila daun yang menjadi tempat utama proses fotosintesis semakin banyak jumlahnya dan semakin besar ukurannya, adanya sinar yang lebih tinggi intensitasnya lebih baik daripada sinar dengan intensitas yang rendah (Pertamawati, 2010).

\section{Berat Total Tanaman}

Pengukuran berat total tanaman dengan penyinaran menggunakan lampu neon dilakukan pada saat pemanenan. Berat total tanaman diukur dengan cara menimbang seluruh bagian tanaman kangkung pada setiap perlakuan.

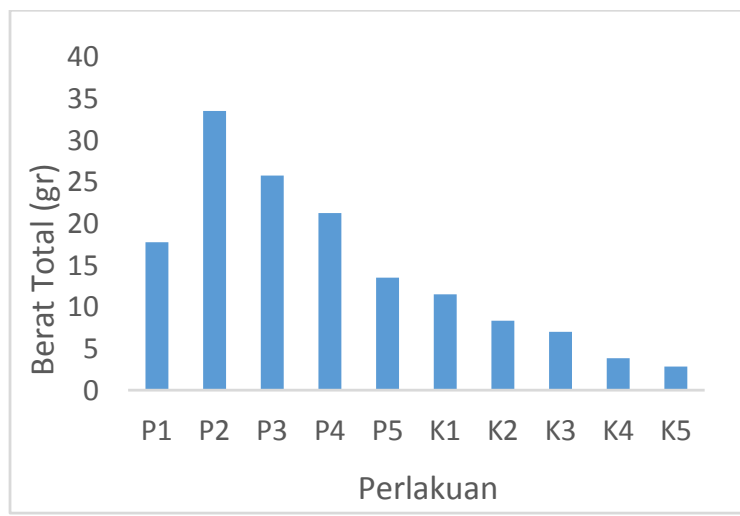

Gambar 5. Grafik Berat Total Tanaman Kangkung (panen)

Berdasarkan hasil pengamatan dapat diketahui bahwa lampu putih 42 watt (P2) memiliki hasil terbaik jika dibandingkan dengan perlakuan di dalam ruang tanam lainnya. Pengukuran nilai berat total tanaman menggunakan analisis varian menunjukkan hasil yang signifikan dengan nilai F-hitung $(8,784)$ lebih besar dari pada nilai F-tabel $(4,49)$. Hal ini dikarenakan bahwa semakin besar intensitas cahaya yang digunakan untuk menyinari tanaman maka intensitas cahaya yang dihasilkan semakin kuat dan tanaman yang diperoleh semakin tinggi karena proses fotosintesis berlangsung intensif. Namun, jika cahaya lampu yang berlebihan maka tidak baik untuk tanaman karena tanaman mempunyai batas maksimum intensitas cahaya yang dapat di terima oleh tanaman. Perlakuan lampu neon dengan watt 40 memberikan hasil terbaik untuk semua variabel pengukuran tanaman karena lampu neon berwarna putiih hampir sama menghasilkan intensitas cahaya matahari (Alhadi, dkk., 2016).

Faktor yang paling mendominasi dalam pertumbuhan tanaman kangkung yaitu cahaya. Kangkung sangat membutuhkan sinar matahari untuk proses fotosintesis, pada sistem hidroponik indoor sinar matahari dapat di gantikan dengan cahaya dari lampu. Lampu yang berwarna putih sangat cocok untuk menggantikan sinar matahari karena menghasilkan intensitas cahaya yang cocok untuk semua tanaman, akan tetapi semua tanaman membutuhkan intensitas yang berbeda-beda. Lampu berwarna putih memberikan intensitas cahaya yang dapat ditangkap oleh semua tananan untuk proses fotosintesis. Hasil fotosintesis akan ditranslokasikan ke seluruh jaringan tanaman melalui floem yang selanjutnya energi hasil fotosintesis akan dipergunakan tanaman untuk mengaktifkan pertumbuhan tunas, daun dan batang sehingga tanaman dapat tumbuh optimal (Lukitasari, 2012).

\section{Berat Akar Tanaman}

Pengukuran berat akar tanaman dilakukan pada saat pemanenan. Berat akar tanaman diperoleh dengan cara menimbang bagian akar tanaman setelah dipisahkan dengan batangnya. Hasil berat akar tanaman dapat di lihat pada gambar 6 . 


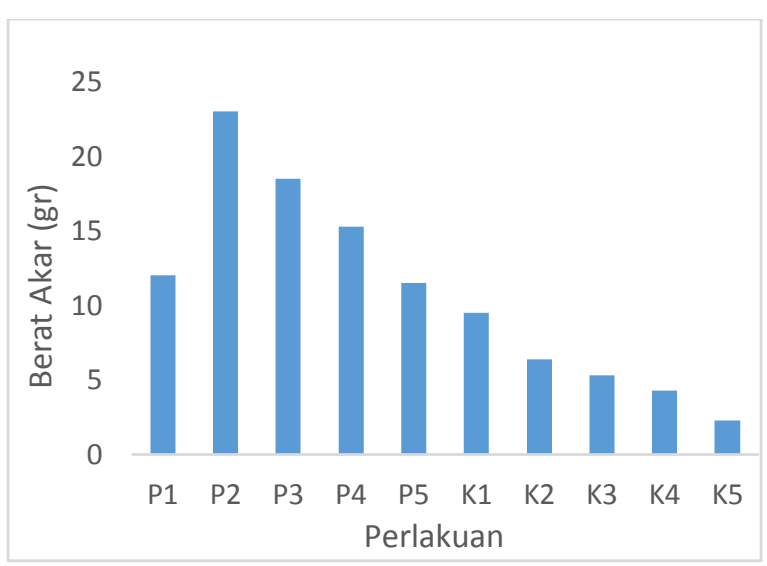

Gambar 6. Data Hasil Berat Akar Tanaman Kangkung pada Setiap Variable

Hasil pengukuran selama penelitian dapat dilihat bahwa berat akar tanaman tertinggi yaitu pada perlakuan P2 dibandingkan dengan perlakuan di ruang tanam lainnya dan berat akar tanaman terendah yaitu pada perlakuan K5. Pada perlakuan menggunakan lampu neon berwarna putih, berat akar tertinggi diperoleh pada perlakuan P2. Sedangkan penggunakan lampu neon berwarna kuning, berat akar terendah yaitu pada perlakuan $\mathrm{K} 5$, hal ini disebabkan karena lampu neon berwarna kuning menghasilkan intensitas yang rendah sehingga berat akar tanaman menjadi berkurang karena tidak terjadi perkembangan terhadap tumbuhan kangkung.

Pengukuran nilai berat akar tanaman menggunakan analisis varian menujukkan hasil yang signifikan dengan nilai F-hitung $(14,190)$ lebih besar dari pada nilai F-tabel $(4,49)$. Pada perlakuan K5 tanaman mendapatkan intensitas cahaya yang sedikit sehingga tanaman tidak dapat melakukan fotosintesis dengan sempurna yang menyebabkan pertumbuhan tanaman menjadi lambat, hal ini menyebabkan penurunan pada berat akar tanaman.

\section{Panjang Akar Tanaman}

Panjang akar termasuk dalam pengukuran hasil produksi tanaman kangkung yang dilakukan pada saat panen dengan pengukuran menggunakan penggaris untuk mengukur akar tanaman terpanjang. Semakin panjang akar tanaman, maka semakin baik akar menyerap nutrisi dalam pot. Akar tanaman akan bertambah panjang dan lebat setiap harinya. Hasil panjang akar tanaman kangkung dapat dilihat pada gambar 7.

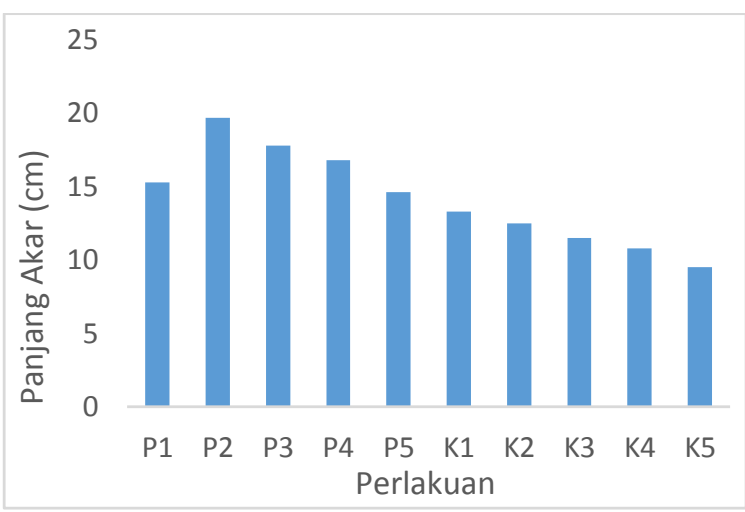

Gambar 7. Grafik Panjang Akar Tanaman Kangkung

Selama penelitian berlangsung diperoleh hasil panjang akar tanaman tertinggi yaitu pada perlakuan P2 dan panjang akar tanaman terendah yaitu pada perlakuan K5. Analisis varian menunjukkan hasil yang tidak signifikan dengan nilai Fhitung $(3,071)$ lebih kecil dari pada nilai Ftabel $(4,49)$, Hal ini disebabkan karena pada perlakuan P1, P2, P3 P4, dan P5, penggunaan lampu putih tidak memberikan hasil yang berbeda nyata begitupun dengan penggunaan lampu kuning. Penggunaan lampu kuning dapat memperoleh panjang akar yang sebanding dengan penggunaan lampu putih, karena lampu kuning dapat memproduksi panjang akar dengan baik tetapi tidak dengan pertumbuhannya (Restiani, dkk., 2015). Hal ini dinamakan etiolasi, ketersediaan cahaya merupakan faktor utama yang mempengaruhi terjadinya etiolasi, dimana tanaman yang hidup di tempat yang minim atau kekurangan cahaya akan membuat hormon auksin dalam tanaman tersebut menjadi aktif, sehingga menyebabkan terjadinya pertumbuhan yang abnormal pada tanaman. Bagian tanaman yang tidak terkena sinar matahari, maka tanaman tersebut akan menghasilkan hormon auksin dalam jumlah yang banyak yang dapat menyebabkan selsel dalam tanaman tersebut memanjang dengan lebih cepat (Rosliana, 2015). 
Umumnya kangkung hanya sedikit menerima cahaya yang berwarna kuning sehingga pertumbuhan tanaman menjadi terhambat dan tanaman lebih cepat layu dan mati. Pertumbuhan panjang akar hanya memiliki sedikit perbedaan dengan penggunaan lampu putih dan kuning. Meskipun demikian, dari hasil pengamatan dapat diketahui bahwa pelakuan dengan penyinaran menggunakan lampu neon berwarna putih menghasilkan akar tanaman lebih panjang dibandingkan dengan perlakuan penyinaran menggunakan lampu neon berwarna kuning.

\section{KESIMPULAN DAN SARAN}

\section{Kesimpulan}

Berdasarkan hasil dan pembahasan di atas, dapat ditarik beberapa kesimpulan antara lain sebagai berikut:

1. Daya lampu 42 watt dengan penyinaran lampu neon berwarna putih memberikan hasil lebih baik jika dibandingkan dengan perlakuan lainnya.

2. Penyinaran lampu neon berwarna putih memberikan hasil yang lebih baik untuk tanaman kangkung jika dibandingkan berwarna kuning.

3. Penyinaran dengan lampu kuning dengan durasi 24 jam tidak berpengaruh nyata terhadap tanaman kangkung.

\section{Saran}

Untuk penelitian selanjutnya, disarankan lebih mendalami fisiologi tanaman, metode hidroponik dan plant factory.

\section{DAFTAR REFERENSI}

Acero. (2013). Pengaruh Warna Lampu LED Terhadap Pertumbuhan Tanaman Krisan. Skripsi. Jurusan Teknik Elektro Fakultas Teknologi Industri Institut Sains dan Teknologi AKPRIND: Yogyakarta.
Alhadi, Dini, D.G., Triyono, S., dan Haryono, N. (2016). Pengaruh Penggunaan Beberapa Warna Lampu Neon Terhadap Pertumbuhan Tanaman Kailan (Brassica oleraceae) Pada Sistem Hidroponik Indoor. Jurnal Teknik Pertanian Universitas Lampung. Lampung 5(1):13- 24.

Lukitasari. (2012). Menakar Kebutuhan Hara Tanaman Dalam Pengembangan Inovasi Budidaya Sayuran Berkelanjutan. Pengembangan Inovasi.

Pertamawati. (2010). Hidroponik Buah Untuk Bisnis dan Hobi. Penebar Swadaya. Jakarta.

Phina. (2014). Pengaruh Pemberian Pupuk Organik Pada Media Tanah Yang Mengandung Timbal $(\mathrm{Pb})$ Terhadap Pertumbuhan Kangkung Darat (Ipomoea reptans Poir). Jurnal Biologi, 20(1): 199-200.

Restiani, R., Triyono, S., Tusi, A., dan Zahab, R. (2015). Pengaruh Jenis Lampu Terhadap Pertumbuhan dan Hasil Produksi Tanaman Selada (Latuca sativa L.) Dalam Sistem Hidroponik Indoor. Jurnal Teknik Pertanian Fakultas Pertanian Universitas Lampung, 4(3): 219-226.

Suyanto, H., Abriana, T.L., Rupiasih, N.N., dan Widyatmika, P. (2011). Pengaruh Intensitas Cahaya Merah $680 \mathrm{Nm}$ Terhadap Laju Pertumbuhan Dan Kadar Klorofil-A Pada Fase Pembibitan Tanaman Tomat. Seminar Nasional Fisika 2011 ISSN 2088-4176. Pusat Penelitian FisikaLIPI Serpong, 12-13 Juli 2011.

Widiastuti, L., Tohari, Sulistyaningsih, E. (2004). Pengaruh Intensitas Cahaya Dan Kadar Daminosida Terhadap Iklim Mikro Dan Pertumbuhan Tanaman Krisan Dalam Pot. Jurnal Ilmu Pertanian, 11(2): 35-42. 